\title{
Agents of Death: Reassessing Social Agency and Gendered Narratives of Human Sacrifice in the Viking Age
}

\author{
Marianne Moen ㅈ \& Matthew J. Walsh
}

\begin{abstract}
This article seeks to approach the famous tenth-century account of the burial of a chieftain of the Rus, narrated by the Arab traveller Ibn Fadlan, in a new light. Placing focus on how gendered expectations have coloured the interpretation and subsequent archaeological use of this source, we argue that a new focus on the social agency of some of the central actors can open up alternative interpretations. Viewing the source in light of theories of human sacrifice in the Viking Age, we examine the promotion of culturally appropriate gendered roles, where women are often depicted as victims of male violence. In light of recent trends in theoretical approaches where gender is foregrounded, we perceive that a new focus on agency in such narratives can renew and rejuvenate important debates.
\end{abstract}

\section{Introduction}

While recognizing gender as a culturally significant and at times socially regulating principle in Viking Age society (see, for example, Arwill-Nordbladh 1998; Dommasnes [1991] 1998; Jesch 1991; Moen 2011; 2019a; Stalsberg 2001), we simultaneously highlight the dangers inherent in transferring underlying modern gendered ideologies on to the past. There is growing awareness that gender norms and roles were prone to contradiction, open to plasticity, and potentially of a fundamentally more fluid nature than what we today consider natural (Clover 1993; Hedeager 2011). As Brit Solli and others (Price 2019; |Solli 1998; 2002; 2004; 2008) have illuminated, Viking Age concepts of gender as related to ritual practice and the proclivities of ritual specialists are especially complex and composite. Despite considerable evidence to the contrary (e.g. Hedenstierna-Jonson et al. 2017; Moen 2019a), modern conceptions of Viking society continue to place women as accessories to male action and/or vehicles for the display of male wealth and prestige-effectively rendering them tertiary agents of their own destiny. Consequently, we find there is value in gendered revaluations of certain narratives. Here we offer a reinterpretation of the oftcited account of Ibn Fadlan among the tenth-century
Rus on the Volga, from a feminist perspective rooted in intersectional theory and concerns with agency and active versus passive voices. We present a number of cases to support the potential for female agency in relation to funerary traditions, specifically related to sacrificial practices. Significantly, though we have situated this discussion in Viking Age scholarship, we believe the themes of gendered biases in ascribing agency discussed here are of broader applicability within archaeological interpretations across much of the discipline.

Gendered biases and academic narratives

Gender as a field of study within archaeology has, since it was first brought into mainstream consciousness in the 1980s, repeatedly demonstrated shortcomings in the depiction of a past populated primarily by active men and passive women (Conkey \& Spector 1984; Gilchrist 1999; Moen 2019b; Wylie 2007). Nevertheless, a tendency remains to rely on stereotypes of 'genderappropriate' behaviour and roles in archaeological narratives, at times not considering whether or not this reflects the material record. Thus, gender in the past arguably remains a niche subject, with many interpretations still reliant on stereotypes (as argued in Dempsey 2019; Moen 2019b). The result of this is 
incomplete and probably quite inaccurate depictions of the past, instead of a more balanced understanding of myriad lived experiences and life histories, whether male or female, young or old, pleasant or tragic.

By using one particular source and its influence on subsequent narratives as an example, we address how normative interpretations based on preconceptions can enter the canon of accepted knowledge claims. Thus, we seek to rejuvenate an old debate on gender and agency, and to reignite interest in how entrenched gendered biases based on modern ways of being and thinking have inadvertently influenced interpretations of past scenarios, which can actually be read in alternate ways. We use agency here in the specific context of human social agency within a defined group. Within this, we take agency as the possibility to do, or act, with intent, and with this intentionality, to influence the wider social fabric of the defined group (Foucault 1982).

\section{The funeral of a chieftain}

Ibn Fadlan's evocative narration of the funeral of a chieftain amongst a group of Rus (Lunde \& Stone 2012; Montgomery 2000) ${ }^{1}$ is rightly famous amongst Viking Age scholars. Describing 10 days of rituals and feasting leading up to the final cremation and burial, the story tells how the dead man is placed in a temporary grave while the accoutrements necessary for his burial are made ready. New clothes are cut for him, alcoholic drink is prepared and a slave volunteers to die with him (Fig. 1). This same slave enjoys an elevated position for the duration of the subsequent funerary preparations, as we will discuss further below. A ship is brought on land to serve as a funerary vessel, and towards the end of the 10 days the chief is exhumed and his body brought on board his ship. Extensive sacrifices are made and grave goods are presented, and the slave who volunteered to die is ritually killed before the ship is set ablaze and a mound raised over the ashes (Lunde \& Stone 2012, 49-54). ${ }^{2}$ Constituting the only eyewitness account of what is commonly assumed to be a Viking Age burial, the source naturally occupies a central role in discussions of Viking Age mortuary behaviour as well as wider discussions of human sacrifice (Hraundal 2013; Montgomery 2000; Price 2010; 2012; Warmind 1995).

Discussions of Ibn Fadlan's account often dwell on the treatment and death of the slave girl. Yet despite this interest, what is rarely-if ever-discussed is her role as an active contributor in her own death. Her agency is lost in narratives that dwell purely on her passive role as a victim. A second aspect which also deserves more attention than it often gets is the role of another female figure who looms large in the narrative, namely the crone known as the Angel of Death, who is described as the leader of the rituals and who ultimately carries out the sacrifice of the girl (Lunde \& Stone 2012, 51). Arguably, narratives characterized by a lack of female agency have come to be associated with a source which in fact could be claimed to contain the very opposite in these two characters, and this article will explore how these women, so often described in passive terms, can equally be seen as socially invested agents.

Ibn Fadlan is too rich a source to be comprehensively discussed in a short paper. It will also be impossible to do justice to the full range of secondary literature, as the source is discussed so widely as to justify being called ubiquitous. Here the focus is firmly placed on re-examining the gendered narrative which has dominated the discourse on this source. Juxtaposing the young slave girl with her older executioner can provide interesting critical views of which female roles have traditionally been considered interesting in academic treatment of the text, and this aligns with broader academic trends in archaeological treatments of social agency and gender, as well as narratives of sacrifice. An argument can be made regarding the promotion of culturally appropriate female roles and the suitability of sacrificial victims with restricted or non-existent agency. Arguably, women as victims of violence and as pawns in rituals aimed principally at increasing male glory or status makes cultural sense in the Western mind-set, more so than does a female ritual specialist who doubles as a sacrificial executioner.

A further argument will be made that the insidious influence of Ibn Fadlan is not always helpful in interpreting archaeological contexts, where it may lead to deterministic interpretations to the detriment of other explanations.

\section{A note on the Rus}

It behoves any discussion which uses Ibn Fadlan to discuss Viking ritual behaviour to establish certain caveats. First among these is the question of who the Rus were, and whether or not they were of Scandinavian origin (for more in-depth discussion of this issue, see Franklin \& Shepard 1996; Montgomery 2000; Price 2010; Raffield 2018). This issue, known as the Normanist controversy, remains the subject of much debate, at times politically charged (Hillerdal 2009, 41-83; Hraundal 2013, 1; Schmid 2018). This does not influence our discussion of the text however, where the focus is directed at the 
Figure 1. 'When a great man dies, the members of his family say to his slave girls and young slave boys: "Which of you will die with him?" One of them replies: "I will".' (Lunde E Stone 2012, 50). The slave girl volunteers to die. (Illustration: Eric Carlson. (C) KHM.)

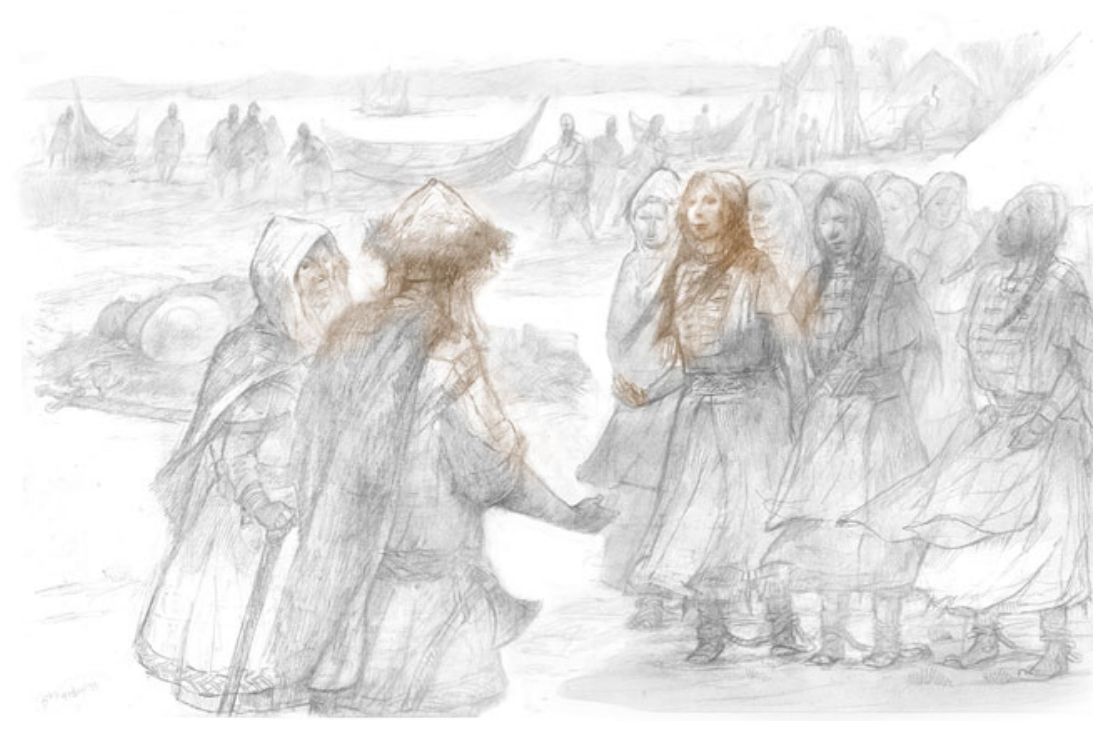

overall influence of Ibn Fadlan's account and its subsequent academic treatment, rather than on the veracity of it.

Though Ibn Fadlan's Risala [report] is widely considered an accurate and truthful telling of what he witnessed on his travels, it should be approached critically on several counts. First, we must consider that Ibn Fadlan was recording customs alien to him from a people who were, according to his descriptions of them, utterly Other (as discussed in Upham 2019, 18-21). Second, we must consider the implications of working only with translations, which themselves originate in two different versions of the original text (Hraundal 2013, 94-6). Third, we must acknowledge that we are working with modern interpretations of a text which is itself interpreted and translated, based on yet other levels of interpretation, namely that of Ibn Fadlan's own cultural lens. Thus, the narrative cannot be read as an objective record, but rather one written by one person with a specific audience in mind. All of this should temper how we read the story (Karras 1988; Price 2010; Upham 2019). Fourth, and finally, we now read it within a specific tradition of knowledge production, which shapes how we understand it in no small degree.

Certainly, Ibn Fadlan does not give a great deal of narrative reflection or space to female social agents in his account; instead they feature mainly as male accessories (e.g. Lunde \& Stone 2012, 47). Indeed, a recent thesis by Tonicha Mae Upham has pointed out that women are given voice only twice in his entire story (Upham 2019). We may believe that Ibn Fadlan wrote about the world as he saw it, but how he saw the world cannot be taken as a reflection of all the intersecting social roles and experiences which can be glimpsed in his story. The crux here is that passive female stereotypes have persisted uncritically throughout academic explorations of his account.

Though his women are silent, and he himself is likewise silent about their motivations and agency (a general issue discussed in Berkey 2013, 57), we can nevertheless be sure that, as living beings, they would have had both. Although his Angel of Death is not given any words, we may presume to speculate that his story may have taken on different layers had he sought to hear the rituals explained from her perspective. Had he likewise sought to understand and record the motivations of the slave girl, we may have been faced with quite a different story altogether.

A sacrifice without a recipient: defining retainer sacrifice The death of the slave girl forms a more or less obligatory part of any discussion of the reality of human sacrifice in Viking Age funerary rituals (Duczko 2004; Hraundal 2013; McLeod 2018; Näsström 2001; Price 2008; Steinsland 2005), and yet it is not without its challenges. In theory, sacrificial schema tend to be directed towards a higher power, designed to alleviate, obtain or avoid certain outcomes (Bourdillon 1980; Green 1999; Hubert \& Mauss 1964; Schwartz 2017). The killing of a companion in a burial ritual falls under a slightly different heading which does not immediately fit with the classical definition of making sacred that the word sacrifice literally means (Hubert \& Mauss 1964). Among 
some scholars who adhere to the strictest definitions of sacrifice (e.g. Edholm 2016; Näsström 2001), sacrificed slaves and retainers are occasionally argued as falling outside human sacrifice proper.

Nevertheless, the retainer sacrifice, though not perhaps a traditional sacrifice in some senses, remains an offering of a human life, either to the deceased, to the gods, or as a part of final tributary rites. It remains a ritualized killing of a human being, for what can certainly be understood as religious purposes, and must therefore take its place within sacrificial schema (Schwartz 2017). This form of sacrifice may not fit with traditional notions of acts of oblation or those meant as communion or exchange with the divine, but it nonetheless fits into a sacrificial economy, where the offering of a human life was considered proper when performing the required final rites and providing for the afterlife of certain types of person within certain social settings. This should also be contextualized with animal sacrifice in burials, and thus linked into a value scheme of things included in final rites. While domestic animals and companion animals may be manifestations of different rituals (domestic animals may be remains of the funerary meal, for instance), there are certain shared aspects such as their inclusion in the final ritual expressions and arguably in the grave goods. Though debates of personhood and value schemes are of relevance to such a discussion (Fredengren 2018; Fredengren \& Löfqvist 2015), we here postulate that retainer sacrifice may be positioned as the ultimate burial offering in such schema. We can envisage it as the final touch to demonstrate the greatness of the deceased, that they occasioned the inclusion of the lives of others in their equipment for the journey into death. What remains unchanged by such speculations is that the retainer sacrifice is a form of human sacrifice, in which a human life is (often violently) taken, in order to complete the final preparation for katabasis.

This paper will not dwell on the motivations behind retainer sacrifices in the Viking Age. Instead, we build on the fairly substantial evidence, both archaeological and written, that such events were part of the social fabric of the time (see Gardeła 2017; McLeod 2018; Naumann et al. 2014; Price 2008, for a summary). Consequently, the killing of the slave girl in Ibn Fadlan is here accepted as a description of a human sacrifice. Equally accepted is that this represents a formalized and not unexpected form of ritualized violence, such as we also find expressed in the archaeological record in other instances of the later Viking Era (Naumann et al. 2014; Price 2008). The finer points of to whom the sacrifice was made remain the subject for another paper.

\section{Willing victims: slave girls as a trope}

Arguably, the death of the slave girl in Ibn Fadlan's account presents the death of a perfect victim. Not only is the slave girl willing, she is resolute. From Ibn Fadlan's perspective and that of his intended audience, and ostensibly for modern readers, the girl in many ways personifies the classic victim of human sacrifice. She is young: the terms used to describe her suggest her age at around 14 or 15 years old (Price 2010, 136), and certainly sexually available. She is also largely disenfranchised and powerless. She is but a slave. And though Ibn Fadlan records that she volunteers for her death (Lunde \& Stone 2012, 50), the question of just how voluntary this was has been raised elsewhere (Hraundal 2013; Price 2010, 104-5; 2012). The flip side of this is that her readiness to die takes on an air of enticement to modern readers of the narrative, perhaps even seductive in its submissive aspects. Once she has volunteered to die, the point is made that she could not change her mind; but the narrative does not indicate such a change of heart. Rather she is described as cheerfully drinking and singing through the days (Fig. 2; Montgomery 2000, 15). She is referred to at one point as 'the slave girl who wanted to be killed' (Lunde \& Stone 2012, 50) and who expresses a desire to join her deceased master in paradise (Lunde \& Stone 2012, 52). She seems content throughout the rituals, at least until the violent end. This is reflected in other accounts as well, where notes are made that the Rus burned slave girls with the wealthy, and that these girls died of their own volition (Lunde \& Stone 2012, 59).

Judith Jesch has pointed to how slave girls play a key part in Arabic sources on the Rus. 'We rarely meet women in these Arab accounts and, when we do, it is as captured slave girls or as the sacrificial victims of suttee' (Jesch 1991, 118), a statement that rings true when reading the narratives. An interesting examination of slave girls as a literary trope can be found in Upham's thesis, which demonstrates how their portrayal followed certain cultural norms in order to depict the exotic Other (Upham 2019). Undeniably, these accounts are told from a male perspective. Not only does Ibn Fadlan rarely give women a voice; his translators, his social actors and his informants are predominantly male. In short, he describes the world through male action and speech, even when describing women acting and speaking. Here it is pertinent to point to feminist critique of 
Figure 2. 'Then they appointed two young slave girls to watch over her and follow her everywhere she went, sometimes even washing her feet with their own hands ... Meanwhile, the slave girl spends each day drinking and singing, happily and joyfully.' (Lunde $\mathcal{E}$ Stone 2012, 50). The Angel of Death prepares the dead man's funerary clothes while her 'daughters' tend to The Girl Who Wishes to Die. (Illustration: Eric Carlson. (C) KHM.)

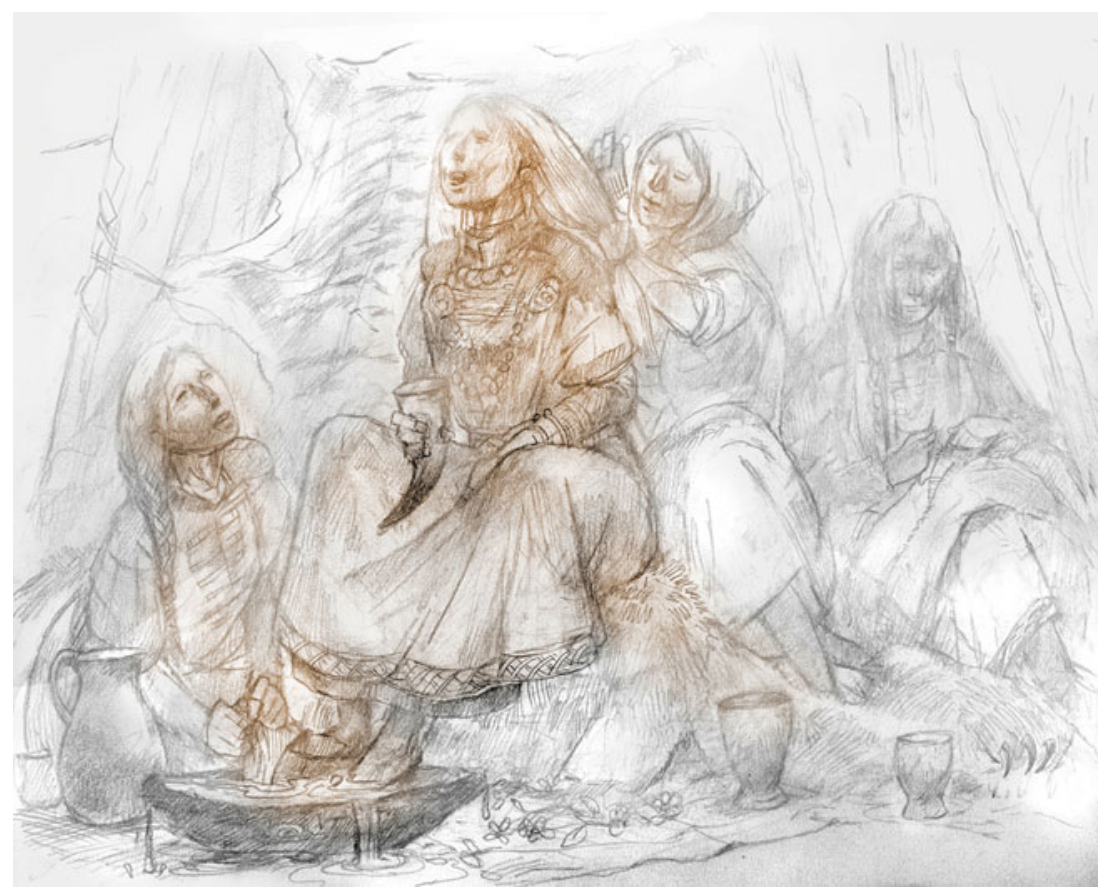

social anthropology's interminable male gaze. If we only ask part of the population how their gender dynamics work, we can hardly expect to achieve a full picture (Moen 2019a, 41-2; Pyburn 2004). Nor does the silence of a social actor in some settings mean that they have no voice or choice of how to use it. We should consider if scholarly voices subsequently have promoted this passivity rather than examining their potential for otherwise obfuscated agency.

Arguably, Ibn Fadlan betrays a fascination with the sexual availability of slave girls (Upham 2019). This is demonstrated in the recurring theme of the sexual part of the funerary rituals (as discussed in Price 2010, 134-5) and in his observations of public sex acts among the Rus. The skewed gender dynamics betrayed by Ibn Fadlan, however, must be seen in context with his time and his task. Whether or not he was playing to an audience or writing to reflect his own observations is beside the point. Though his voyeuristic gaze has certainly attracted comment (Karras 1988, 46; Raffield 2018), it is pertinent to question the enduring challenges inherent in the continued use of the source, which tends not to question the lack of female social agency. This can be examined in light of a wider investigation of how identities were configured, as we explore below.

Instead of simply promoting a narrative of a young and helpless victim, there is room to explore the slave girl's voluntary sacrifice as a conscious act intended to take back control over her own destiny.
Hilda Ellis $(1969,57)$ suggests that by choosing to die with her master, the slave girl earns the right to call him her husband, thereby significantly improving her social standing and position in the afterlife. We should bear in mind that the afterlife was presumably perceived as rather more tangible than it is to most modern Western conceptions. To the slave girl, this may have been a rational gamble aimed at improving an otherwise confined and constrained existence, an activated agential manifestation of her desire to improve her destiny. If, as we argue below, being a slave was a defining trait of her social identity, breaking out of this to achieve some form of self-determination does not seem so illogical. There is a parallel in a death described in Gautrek's saga (as also brought forward by Ellis 1969), where a servant is allowed to die with his master. This voluntary death ensures his welcome into the realm of Odin, which was for some individuals perhaps an afterlife unachievable in any other way. Joining these perspectives together, we might envision a brave act of self-determination in the slave girl's willingness to face immolation, rather than a passive act of submission on her behalf.

Which of you will die with him?

A noteworthy passage is found in Ibn Fadlan's description of the selection of the sacrificial victim: 'When a great man dies, the members of his family say to his slave girls and young slave boys: "which of you will die with him?"' (Lunde \& Stone 2012, 
50). Though it is subsequently noted that it was customarily the slave girls who offer to die, it is interesting here to pose the question of how the narrative might have differed were it a slave boy who volunteered. Would the ensuing rituals have looked the same or very different, and would the scholarly treatment of the text have been different, had it been a male slave at the end of the knife?

If we consider the intersecting aspects of identity at play in the communication and understanding of a person's being, we may ask whether or not it is the slave or the girl part of the victim's identity which is of the highest importance here. Could we envisage a social status defined by lack of personal freedom, the identification as a commodity rather than a person, which influenced whether someone was configured as a social agent or not? The rhetoric of slavery is complex. It will certainly not be suggested here that a single motive, ideology or ruling norm can be suggested for all such scenarios, but it is relevant that a tendency to commodify the subjects of slavery (i.e. slaves), often hinges on dehumanizing them into states of non-agency-a common mechanism of oppression (Raffield 2018, 683). Furthermore, it is becoming widely recognized that being human was no guarantee to being universally perceived as a person in the Viking Age (Eriksen 2020; Lund 2017). Following such considerations of what creates social identity, it may be suggested that freedom, or the lack thereof, may be of more relevance to the configuration of personhood than, for example, gender.

The emphasis on girls and boys may hold a key to understanding one configuration of social status, especially when combined with loss of freedom. In concept, a slave girl or a slave boy may perhaps be so interchangeable as to be treated, thought of and used in the same ways, with little reference made to biological sex. In such cases, the character of slave is the paramount identifier, taking precedence over other aspects of identity. A further hint towards such a possibility is found in the account of Miskawayh of a raid by the Rus on Bardha'a in 943, wherein he notes that in their plundering, pillaging, ransoming and general mayhem 'They kept the women and boys, whom they raped and enslaved' (Lunde \& Stone 2012, 149).

There are hints at such a configuration in other accounts as well. Another Arabic source tells how when one of the Rus died, he was buried with his possessions, his wife and his slave, if he happened to be fond of him (Lunde \& Stone 2012, 151). In fact, out of five Arabic sources with references to human sacrifice, two stipulate the possibility of a man alongside or instead of a woman (Upham 2019, 23). These are points that ought to weigh heavily on discussions which foreground the sexual exploitation of female slaves, as they can be argued to indicate a worldview among the Rus wherein the sex of a slave was not necessarily a motivating factor in their treatment, either good or bad. Though there is not room to give this subject full justice here, these hints take on further significance in conjunction with explorations such as Britt Solli's work on the inherent queerness of Norse mythology (|Solli 1998; 2002; 2004; 2008). Together with other remnants, such as the recorded verses of Warner of Rouen, who satirizes an Irishman's experience of slavery at the hands of Viking raiders, including his being used for sexual purposes (Christiansen 2002, 26), this opens new avenues of understanding the interrelationship of gender and personhood. Relatedly, Vanggaard $(1972,76-81)$ notes that 'In the old Norse epics the allegation " $\mathrm{X}$ uses $\mathrm{Y}$ as his wife" is an intolerable insult to $Y$ but casts no adverse reflection on the morals of $X^{\prime}$. The sexual intentions and agency of individuals as dominant actors seem to have been, at least in some cases, more important in terms of gender/ sexual identities than the physical expressions of sexual conduct themselves. These examples support the need to re-envision notions of how sexual objects and sanctioned sexual acts were understood in a wider perspective for Viking Age societies. From this, perhaps it may be appropriate to suggest the fascination with slave girls may be something of a modern imposition on the ultimate reading of these sources.

\section{The Angel of Death}

Coming to the second manifestation of what we read as female agency in Ibn Fadlan's account of the funeral, the sinister personage of the woman termed the 'Angel of Death' is often remarked upon. This shadowy figure is rarely granted as much interest as the slave girl (Montgomery 2000; Price 2002; 2010; Upham 2019), and yet she provides a glimpse into sacrificial ritual behaviours and their practitioners such as ought to make her very interesting indeed. She is described as the one who leads the rites (Lunde \& Stone 2012, 50-53). She is also the one who displays the most violent behaviour. She encourages the girl to imbibe a drink to the point of inebriation, muddling the girl's wits, numbing her to the realities of her final moments. The Angel of Death literally leads the girl to her death and directs the roles of the men who participate in the killing. She herself is the only one who sheds blood in the completion of the ritual. Throughout, she maintains control of the expression and sequence of 
events-we consider it clear that she is in charge of the occasion, acting with knowledge, intent and purpose (Lunde \& Stone 2012, 53).

Set in context with Ibn Fadlan's tendency to dwell on age and beauty, his description of the Angel of Death is striking. Translations vary somewhat, but the essence seems to be that she is a crone, corpulent (Montgomery 2000, 15) or 'thick bodied' (Lunde \& Stone 2012, 51). McKeithen has perhaps the most confusing translation, with his 'I saw her as a young, old witch, massive and somber' (McKeithen 1979, 141). That she is of sinister aspect, all agree. Montgomery has pointed out that her role is not unprecedented, and that women who sacrifice are known from other sources (Montgomery 2000, 15). Neil Price has connected the title Ibn Fadlan gives her, Malak Al-Mauf, which in Islam is the angel who separates the soul from the body at death, with that of the Valkyrie, the chooser of the slain (Price 2010, 133).

A further indication of this figure's potential significance can be surmised in her being there at all. For what is essentially understood as a mobile group of traders, her very presence makes for an intriguing starting point for re-evaluating her social significance and position. Her inclusion can thereby indicate her as an integral ritual specialist of importance to the group.

A number of questions arise when we consider the Angel of Death's role more closely. Beyond explicitly leading the rituals, she is also described as being in charge of sewing and arranging all the things which the dead man needs for his funeral (Montgomery 2000, 15). Ibn Fadlan describes the division of the deceased's property, noting how one third of his wealth was allotted to the deceased's family, while one third was set out for making the clothes the dead man needed for burial and another for the nabidh ${ }^{3}$ (Lunde \& Stone 2012, 49). It can be surmised from this that proper attire was considered important in a funeral, and from this one can speculate that the task of making these clothes was one of high importance carrying a certain prestige with it. Overall, she seems integral to several major aspects of the funeral preparations and rituals.

A further feature of interest is that she is described as the one who spills the blood of the slave girl (as discussed in Upham 2019, 41). Hers is the hand that holds the dagger, 'plunging it again and again between the girl's ribs' (Lunde \& Stone 2012 , 53). This act of aggressive violence sits rather uncomfortably with reigning stereotypes of the roles of women in the Viking Age embedded in modern scholarship, which are ultimately based on western ideals of accepted feminine behaviour
(Arwill-Nordbladh 1998; Moen forthcoming). The cultural reticence which faces any discussion of women's capacity for violence can be further challenged by this figure who shows no qualms in her enactment of violence and her subsequent academic treatment. This aligns with a new focus on gender in the Viking Age which seeks to change such reigning stereotypes (Danielsson \& Thedéen 2012; Hedenstierna-Jonson et al. 2017; Moen 2019a; Price et al. 2019). We may also link the violence of the final ritual with the possibility that it was necessary for the slave girl's entry into the afterlife with her master (Fig. 3). Her seemingly gratuitously violent end may have been a way of approximating for her a death by combat, which may have been seen as necessary to grant her entrance to a place where she might otherwise not have been able to go.

In many ways, the Angel of Death presents an unappealing appearance to modern eyes. She is shown as violent, and old. She is ugly. And she is fat. She acts single-mindedly and without mercy. Altogether, this makes her far less emotionally engaging to modern readers than the young girl whose life she is socially tasked with taking. Thus, though her role in the entire funerary proceedings can be argued as integral, she has not been the focus of much academic interest. It seems to us thereby that she has been unduly relegated to a position of less importance in modern uses of this narrative than the source justifies.

The presence of women as ritual specialists is well known within Viking Age contexts in the form of the Volva or seeress (Gardeła 2014; 2016; Heide 2006; Price 2002; Solli 2002). The parallel between the Angel of Death and the Volva has been drawn before (Price 2010). Despite a wealth of discussions regarding the important roles of such women in Viking society, their social position has proved hard to trace in many ways (Solli 2002; Steinsland 2005; Sundqvist 2007). Written sources tell us that Volvas wielded magical staffs (the Norse word völva literally means 'staff-bearer'), and that they were generally feared and considered dangerous because of their access to the supernatural. Yet archaeologically, graves containing their eponymous staffs are usually found in distinctly well-to-do, elaborate burials (for a detailed discussion of such graves, see Price 2002), suggesting that such women were honoured and respected. Ibn Fadlan does not record the Angel of Death wielding a staff, though this can hardly be taken as evidence against such a comparison. In any case, her role must be recognized as that of a ritual specialist of some sort-whether Volva or not - and one whose function and demeanour made a 


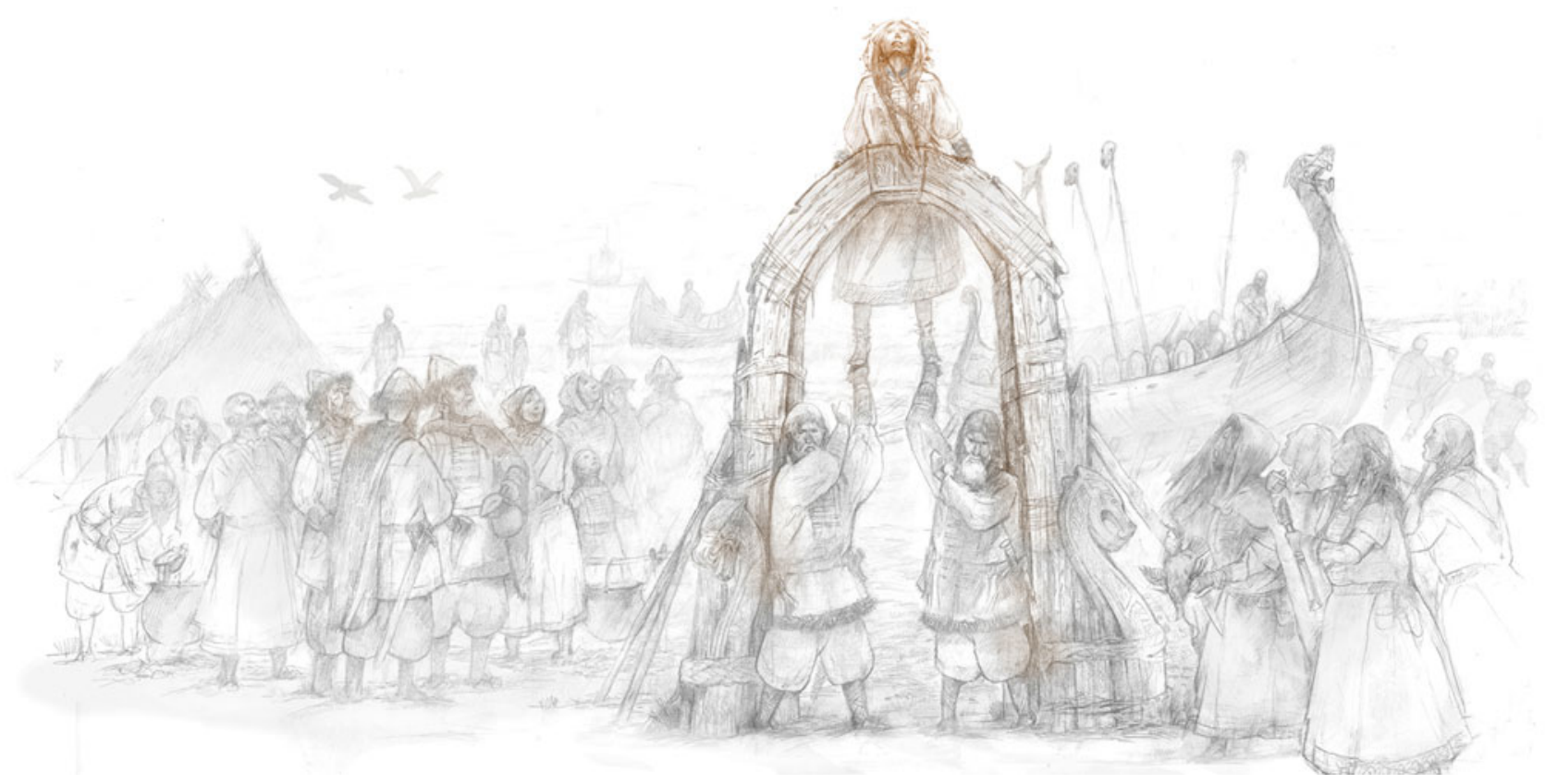

Figure 3. 'There I see my father and my mother ...' (Lunde E Stone 2012, 52). The funerary ritual begins and The Girl Who Wishes to Die looks on paradise. (Illustration: Eric Carlson. (C) KHM.)

lasting impression on Ibn Fadlan to warrant such detailed inclusion in his record of the events.

The possibility of female cult leaders also appears in the women termed the 'daughters' of the Angel of Death, assigned to the slave girl as her servants for the duration of the funerary process. From the moment the slave girl volunteers to die, they watch over her and serve her, even washing her feet on occasion (Lunde \& Stone 2012, 50). Beyond this, little is said about them. Perhaps they were acolytes to the Angel of Death, rather than her biological or adopted children. Regardless of their individual identities, that these women became the servants of the slave girl illustrates her enhanced social status upon becoming the willing sacrificial victim, testifying to the girl's new privileges and her new (if brief) role in the group. Coming back to how we may envisage her identity as shaped by the overarching determining trait of slave before her volunteering to die, we can again see the tangible results of her asserted agency.

A final note on the agency of the women involved in this sacrificial ritual is seen in one of the last acts of the slave girl. Upon being led to the ship for the final sacrifice, the slave girl removes two bracelets which she gifts to the Angel of Death and two anklets that she gifts to the daughters (Lunde \& Stone 2012, 52). In this, we can see yet another indication of her elevated status. This is potentially significant from several angles: did slaves in Viking society usually command private property of this kind to dispose of, or was this a part of her special treatment as the intended sacrifice? As it appears, she has acquired a position of status and wealth from which to reward those who have helped her transition into this important role and honoured status, even if she achieves it through the vehicle of a violent death. In the Foucauldian sense, the girl, powerless as a slave, is recalcitrant (sensu Foucault 1982) in her becoming 'The Girl Who Wishes to Die'. Her engagement with this final opportunity of defiance through compliance allowed her to transcend her status in both the living world and the afterlife in ways otherwise entirely out of her reach in either.

\section{Narratives of sacrifice and archaeology}

Tracing human sacrifice archaeologically is fraught with complications, not least of which is that the true nature of archaeology means we can never know what caused a particular deposition: we may only interpret. Thus, archaeologists can at times appear rather coy about whether or not to deem something a sacrifice, particularly of the human variety (Berggren 2006; Edholm 2016; Fredengren \& Löfqvist 2015; Green 1999; Schwartz 2017). Keeping to discussions centred on the Viking Age, it is fair 
to say that Ibn Fadlan has remained an important presence in dialogues revolving around human sacrifice. Largely lacking the bog bodies of earlier periods (Bukkemoen \& Skare 2018; Giles 2009; Monikander 2010), the main bulk of Viking Age material which can be interpreted in a sacrificial light is made up of multiple burials where one body shows signs of differential treatment when compared to another, such as evidence of terminal violence, bound feet or hands and/or other forms of violent treatment or restraint (Engdahl 1990; McLeod 2011; Naumann et al. 2014; Price 2008). Typically, these are interpreted as the 'retainer sacrifices' discussed above, while some scholars prefer to designate such graves as 'deviant' and others prefer the less decisive category of 'atypical' burials. One such burial is the Ballateare grave, which offers insights into the potential limitations of preconceived gendered narratives associated with possibly sacrificial archaeological contexts.

\section{'An offering .... to reflect the power and wealth of} the $\mathrm{man}^{\prime 4}$

The Ballateare grave from Jurby on the Isle of Man is frequently cited in discussions of human sacrifice in the Viking Age (Fig. 4; Bersu \& Wilson 1966; Eriksen 2020; Gardeła 2013; 2014; McLeod 2018; Price 2008; Symonds et al. 2014; Wilson 2008). More importantly, it is often tied to Ibn Fadlan's narrative.

Excavated in 1946, the burial mound measured $12 \mathrm{~m}$ in diameter and $3 \mathrm{~m}$ in height (Bersu \& Wilson 1966, 46) and proved to contain complex ritual remains in addition to the main burial. The grave itself was cut into the ground beneath the mound (Bersu \& Wilson 1966, 46) and contained the fragmentary skeletal remains of a man estimated to have been between 18 and 30 years old at his time of death (Gardeła 2014, 31; Wilson 2008). He was buried with numerous accompanying material goods, including a sword with silver-inlaid hilt, an iron-bossed shield, a knife and three spearheads. Traces of ritual activity abound in the grave. The sword and other implements had been deliberately damaged prior to being placed in the grave (Bersu \& Wilson 1966; Gardeła 2014, 31). The subsequent construction of the mound was completed by stacking strips of turf which were not local in origin, another potentially meaningful act (Bersu \& Wilson $1966,51)$. The main attraction in this burial to those interested in human sacrifice, however, comes in the form of a body found in the upper layers of the mound. This was judged as that of a woman between 20 and 30 years old, who was interred in a prone position, with her arms stretched above her head and

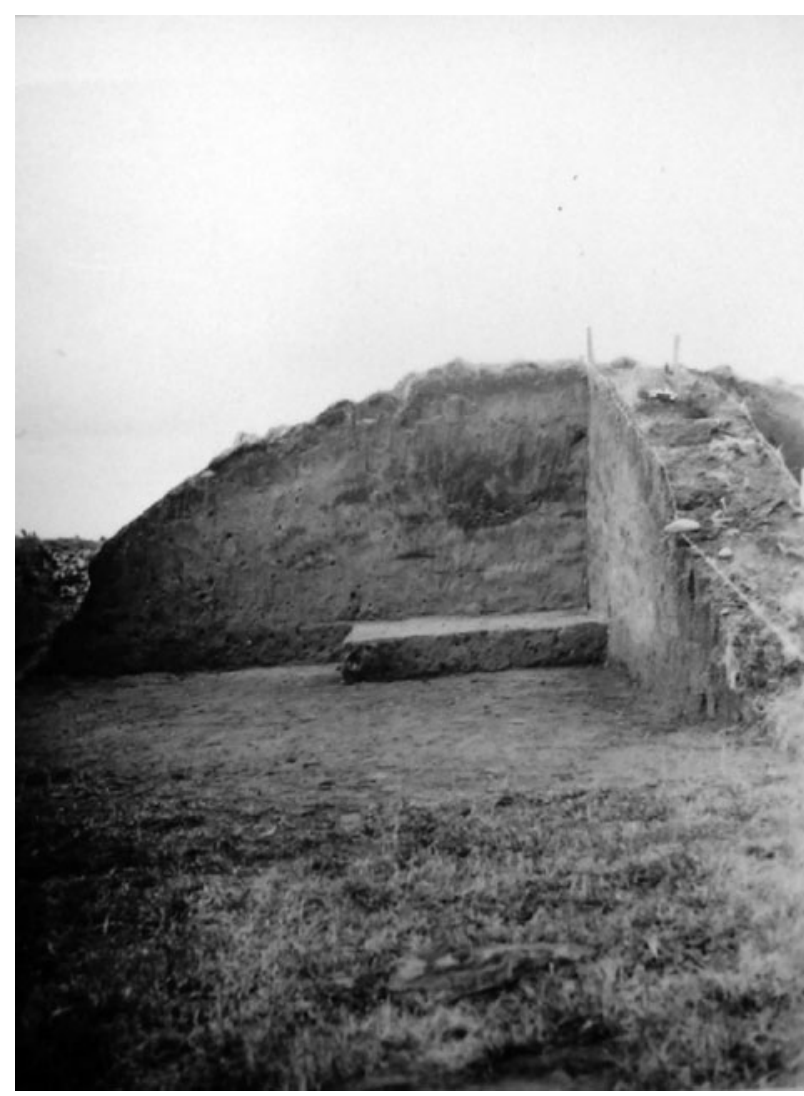

Figure 4. The mound at Ballateare during excavation. (Reproduced with permission. (c) Manx National Heritage.)

with the back of her head missing (Fig. 5; Bersu \& Wilson 1966, 46). The position of her body indicates she was placed in the mound after rigor mortis set in, so she may have been positioned there after death rather than killed on the mound (Bersu \& Wilson 1966, 51). Above her was a layer of burned animal bone (Bersu \& Wilson 1966, 47), completing the impression of extensive ritual and potentially sacrificial violence.

Bersu and Wilson's original interpretation (1966) is confident that this was a human sacrifice in the style of Ibn Fadlan, an interpretation that has echoed through academic treatment of the grave since (see references above). And yet it is worth considering this burial and its interpretation from several angles.

First, we cannot know if the body of the woman was a deposition simultaneous with the main burial. Alternative explanations may be found in the possibility that her placement was part of a later ritual carried out in an established ritually potent spot-part of the pre-existing sacred landscape. Secondly, foul 


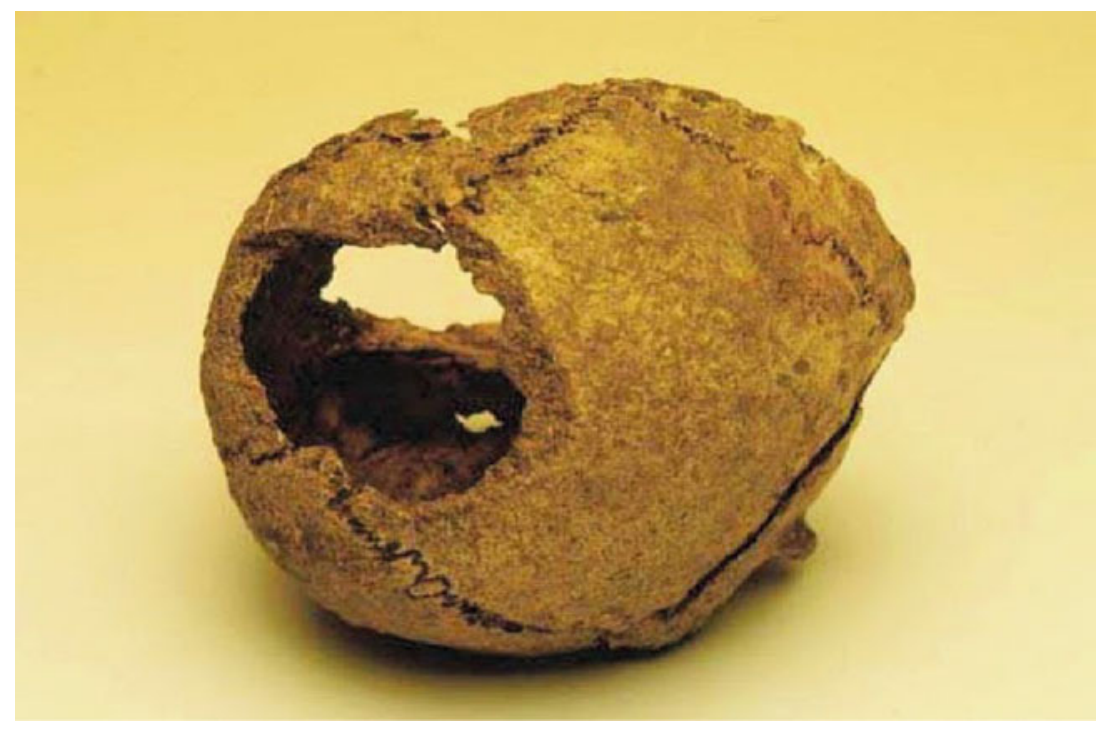

Figure 5. The skull of the upper body in the Ballateare mound. (Photograph: 1966-0373/11, reproduced with permission. (c) Manx National Heritage.)

play cannot be ruled out either. We do not know if the recorded blow to her head was posthumous: as David Griffiths $(2010,83)$ has pointed out, there are other viable explanations, such as death by disease. Moreover, as a recent article has indicated, the cranial injury is not consistent with other cases of sacrifice in Scandinavian contexts, though it is comparable to known battle injuries (Weale 2019, 806). Thirdly, it is worth remembering that the distance between the Rus on the Volga and the Vikings in the Isle of Man is considerable, not just physically but also very likely culturally, and so any comparison between Ibn Fadlan's account and this particular grave needs to consider the cultural contexts and influences relative to both.

Superseding these concerns, however, is how this burial plays into archaeological expectations. The original excavator, who came to this burial from another on the Isle of Man, the famous Balladoole boat-grave site, saw indications of a retainer sacrifice at both graves, each in the form of a young woman interred with a deceased male (Bersu \& Wilson 1966, 90-91). In a discussion which owes much to Ibn Fadlan, Bersu and Wilson demonstrate that they have no doubt of the reality of such rituals, and fix these two burials as concrete examples reflecting such practice (Bersu \& Wilson 1966, 90-91). While not doubting the likelihood of a sacrificial interpretation, it is worth pausing to consider a recent reassessment of the skeletal material from Balladoole which judges that the grave contained exclusively male remains, though from several individuals (Weale 2019), and to ask whether or not the published interpretation would have looked quite the same had this been the assessment of the original report.

Howard Williams' discussion of the fascination the Ballateare burial holds for archaeologists has pointed out how it has been used to gratify and support narratives of presumed Viking norms of keeping concubines and slaves and sacrificing them (Williams 2016). In line with this concern, it is fair to say that this narrative of the Vikings has been left to hinge on rather tenuous links at times. Either grave can support many alternative interpretations which ought to be examined alongside the particular one of slaving and sexual exploitation. By granting Ballateare status as an archaeological confirmation of Ibn Fadlan, we run the risk of reductionist reasoning and simplified interpretations. As Williams (2016) points out, we ought not to fixate on single contexts such as this to support a written source: it can create doubtful circular reasoning which is not helpful to the discussion of human sacrifice, nor likely to promote the development of reliable knowledge.

By allowing modern readings of Ibn Fadlan and his commodified slave girls to set the expectations for what a human sacrifice in the Viking Age ought to look like, we risk ignoring some very important considerations and indeed overlooking some potential comparisons which could add considerable weight to any number of alternative interpretations. The positioning of the Ballateare woman's body is not comparable to most other cases of possible retainer sacrifice, which are commonly found placed within the primary grave (Gardeła 2017; Price 2008). Her death, assuming the head injury was the cause, is not in any way like the death described by Ibn 
Fadlan. With this in mind, we would like to turn attention to how gender can influence the direction of specific interpretative narratives. Juxtaposing this burial with others in which the roles of deceased and possible retainer are reversed with a possible male sacrifice interred with a female, a different explanation may be apparent.

\section{'A man executed for murder and rape'}

An example that crystallizes the point made above about gendered narratives can be found in Wilson's discussion of the Ballateare grave and other supposed sacrificial contexts (Wilson 2008, 28-9, 33-4). His presentation judges Ballateare to be an open-and-shut case of retainer sacrifice, whilst his suggestion for the double burial at Gerdrup in Denmark is rather different. The Gerdrup grave contains the body of a female accompanied by grave goods, found next to a male showing evidence of death by hanging as well as of having had his feet bound (Bennike 1985; Price 2008, 266). Revealingly, Wilson here suggests that this may be the body of a man 'executed for murder or rape buried alongside his victim' (Wilson 2008, 34). Whilst such an explanation is not untenable, a similar interpretation ought surely then to be extended to the bodies at Ballateare, with its peculiarities of death and placement.

Other examples which invite a similar explanation are documented in Leszek Gardeła's (2017) book on deviant burials in the Middle Ages. Here we find two examples from Denmark reminiscent of the Ballateare constellation. Each comprises a supine burial with another prone body in a layer above, showing evidence of violent death (Gardeła 2017, 106). One of these, at Lejre (grave no. 55), is often interpreted as a slave with his master. Another, at Stengade in Langeland (grave FII), is often represented as two executed criminals. In both of these burials, both bodies are male (Gardeła 2017, 106). A discussion by Bo Jensen of sacrificial graves in the form of double burials and decapitations notes seven such burials, of which one is a male with a female 'victim', two are female with male 'victims' and four are male with male 'victims' (Jensen 2016, 9). Such burials, though not common, may denote a particular form of sacrificial conduct, represented by the death of a miscreant, perhaps as a gift to the gods upon the death of an important individual. They may also be classed as possible retainer sacrifices. However, their interpretation ought not be dependent on the gender of the deceased a priori, providing the material expressions are so similar as to invite comparison, as is the case with the material highlighted here.
As a final consideration, it is worth asking how the interpretations of Ballateare might have read, had it not invited such immediate comparisons with Ibn Fadlan. We have already seen how reversing the gender of the bodies may have worked by comparing it to Gerdrup, but we may also ask how age may have played a role, or how it may have looked had both burials been furnished. It is also interesting to ask what might have been the most common interpretations had there never been an Ibn Fadlan. Though these cannot be answered, they may enable a more nuanced view of all the social actors involved in these rituals, not just the ones who did but also the ones who were done to.

\section{Conclusion}

A point to take away from the above is how Ibn Fadlan's male-focused narrative and, more importantly, subsequent scholarship using his account have coloured the expectations we hold on how gendered identities feature in interpretations of sacrificial remains. Female sacrificial victims make cultural sense to us: to see women sacrificed accompanying a male burial is logical within the context that many postulate of the exploitative gender norms of the Viking Age. By contrast, male sacrificial victims, especially when accompanying a female burial, frequently occasion a different response. In such cases, an explanation is necessary that explicitly ignores the possibility of female social agency, power or prestige, or any value over a male life. Instead, the men buried with women tend to be explained either as anomalies or criminals-even the deceased woman's own rapist. The gendered difference here lies in the agency envisaged: women as passive victims go unquestioned, but men in the same circumstance retain their social agency and remain active agents, even in their own punishments. These differential interpretations need to be critically evaluated against the reality of the archaeological material.

We would like to suggest that we leave aside normative expectations and instead examine the materials at hand, which may give rise to interpretations less reliant on ideas of passive sacrificed slave girls or social miscreant men. Instead, we should at least consider the possibility for dynamic sacrificial practices, reflective of the possibilities that females may potentially have been active agents in such scenarios, and that males could be equally exploited for ritual purposes, as for example in association with powerful women. Rather than the straightforward retainer sacrifice or suttee interpretations-with all of their exploitative baggage - we may consider that people 
on both sides of the sacrificial knife might have been active social agents with their own agenda, goals, associations and implications when it comes to sacrifice and funerary rituals.

Returning to the theme of Ibn Fadlan's silent women, it is perhaps time to examine uncomfortable ideas of women acting against type. Under new scrutiny from a more gender-aware perspective, his narrative gives equal reason to argue for women in significant ritually charged roles, rather than that they demurely submitted to fates already determined for them. We wish to conclude by returning to the dangers of disenfranchising social players in the past based on the voices we hear, or perhaps expect to hear, rather those we do not. In the slave girl's death, instead of the exploitative murder of an unwitting victim, if we look we can also see a decisive act of self-determination. Instead of a silent and sinister crone, we could see a female ritual specialist in full charge of the transformative proceedings of the funerary ceremony ushering a deceased lord into the afterlife bedecked in his proper finery, and delivering a girl-elevated through her own courage to a position of respect-into the company of the gods. The possibilities in the narrative depend simply on from where, and from whose eye, we choose to view the story.

\section{Notes}

1. There are numerous translations of Ibn Fadlān's account. Adding to the complications in using the text is that the original has not survived, and current translations rely on two different records of the original text (Hraundal 2013). Here we reference some of them, but rely mainly on Montgomery (2000) and Lunde and Stone (2012).

2. This is necessarily an abbreviated sequence of events: for the full account, the reader is referred to one of the many translations of the text (Lunde \& Stone 2012; Montgomery 2000).

3. An intoxicating, alcoholic drink.

4. From Bersu and Wilson's discussion of the female body in the Ballateare mound, the full quotation states: 'there can be little doubt, to my mind, that the upper burial at Ballateare represents such an offering. It presumably reflects the power and wealth of the man buried in the barrow' $(1966,91)$.

\section{Acknowledgements}

This research is undertaken as part of the project 'Human Sacrifice and Value: the limits of sacred violence', funded by the Norwegian Research Council (PI Rane Willerslev; FRIPRO HUMSAM, project 275947). We wish to express our gratitude to the editors and two anonymous peerreviewers for constructive reviews which helped strengthened this work. We also thank Andrew Johnson and Jude Dicken at Manx National Heritage for assistance with the Ballateare and Balladoole material, Leszek Gardeła for comments and discussions of the same, and Rebecca Cannell for insightful comments on the text and central arguments. Thanks also to Marie Weale for sharing her research and to Svein Gullbekk and Sean O'Neill for insightful discussions and comments during the preparation of the text.

Marianne Moen
Department of Ethnography, Numismatics, Classical
Archaeology and University History
Museum of Cultural History
University of Oslo
Norway
Email: mamoen@khm.uio.no
Matthew J. Walsh
Department of Ethnography, Numismatics, Classical
Archaeology and University History
Museum of Cultural History
University of Oslo
Norway
Email: Matthew.walsh@khm.uio.no

\section{References}

Arwill-Nordbladh, E., 1998. Genuskonstruktioner i nordisk vikingatid. Förr och nu. [Constructions of gender in the Nordic Viking Age: past and present]. Doctoral thesis, University of Gothenburg.

Bennike, P., 1985. Paleopathology of Danish Skeletons: A comparative study of demography, disease and injury. Copenhagen: Akademisk Forlag.

Berggren, Å., 2006. Archaeology and sacrifice: a discussion of interpretations, in Old Norse Religion in Long-term Perspectives: Origins, changes and interactions, eds A. Andrén, K. Jennbert \& C. Raudvere. Lund: Nordic Academic Press, 303-7.

Berkey, J., 2013. Women and gender in Islamic traditions, in The Oxford Handbook of Women and Gender in Medieval Europe, eds J. Bennet \& R. Karras. Oxford: Oxford University Press, 52-69.

Bersu, G. \& D.M. Wilson, 1966. Three Viking Graves in the Isle of Man. London: Society for Medieval Archaeology.

Bourdillon, M.F.C., 1980. Introduction, in Sacrifice, eds M.F.C. Bourdillon \& M. Fortes. London: Academic Press for the Royal Anthropological Institute of Great Britain and Ireland, 1-28.

Bukkemoen, G.B. \& K. Skare, 2018. Humans, animals and water: the deposition of human and animal remains in Norwegian wetlands. Journal of Wetland Archaeology 18, 35-55. 
Christiansen, E., 2002. The Norsemen in the Viking Age. Oxford: Blackwell.

Clover, C., 1993. Regardless of sex: men, women, and power in early northern Europe. Speculum: $A$ Journal of Medieval Studies, 68, 363-87.

Conkey, M.W. \& J.D. Spector, 1984. Archaeology and the study of gender. Advances in Archaeological Method and Theory 7, 1-38.

Danielsson, I.-M.B. \& S. Thedéen, 2012. Gender questions, in To Tender Gender: The pasts and futures of gender research in archaeology, eds I.-M.B. Danielsson \& S. Thedéen. Stockholm: Stockholm University Department of Archaeology and Classical studies, 9-16.

Dempsey, K., 2019. Gender and medieval archaeology: storming the castle. Antiquity 93, 772-88.

Dommasnes, L.H., [1991] 1998. Women, kinship, and the basis of power in the Norwegian Viking Age, in Reader in Gender Archaeology, eds K.H. Gilpin \& D.S. Whitley. London: Routledge, 337-45.

Duczko, W., 2004. Viking Rus: Studies on the presence of Scandinavians in Eastern Europe. Leiden: Brill.

Edholm, K.A., 2016. Människooffer i fornnordisk religion. En diskusjon utifran arkeolgiskt material och källtexter [Human sacrifice in Nordic pre-Christian religion. A discussion from archaeological material and written sources]. Chaos 65, 124-48.

Ellis, H.R., 1969. The Road to Hel: A study of the conception of the dead in Old Norse literature. New York (NY): Greenwood Press.

Engdahl, K., 1990. Människooffer i gravar i Skandinavien under yngre jernalder [Human sacrifice in burials in Scandinavia in the late Iron Age]. Unpublished undergraduate thesis, University of Stockholm.

Eriksen, M.H., 2020. 'Body-objects' and personhood in the Iron and Viking Ages: processing, curating, and depositing skulls in domestic space. World Archaeology 52(1), 103-19.

Foucault, M., 1982. The subject and power, in Michel Foucault: Beyond Structuralism and Hermeneutics, by H.L. Dreyfus \& P. Rabinow. Chicago (IL): University of Chicago Press, 777-95.

Franklin, S. \& J. Shepard, 1996. The Emergence of Rus, 750 1200. London: Longman.

Fredengren, C., 2018. Becoming bog bodies sacrifice and politics of exclusion, as evidenced in the deposition of skeletal remains in wetlands near Uppåkra. Journal of Wetland Archaeology 18(1), 1-19.

Fredengren, C. \& C. Löfqvist, 2015. Food for Thor: the deposition of human and animal remains in a Swedish wetland. Journal of Wetland Archaeology 15, 122-48.

Gardeła, L., 2013. The headless Norsemen: decapitation in Viking Age Scandinavia, in The Head Motif in Past Societies, eds L. Gardeła \& K. Kajkowski. Bytowie: Museùm Zachodniokaszubuskie, 88-155.

Gardeła, L. 2014. Viking death rituals on the Isle of Man, in Viking Myths on the Isle of Man, eds L. Gardeła \&
C. Larrington. Nottingham: Centre for the Study of the Viking Age, 30-38.

Gardeła, L. 2016. (Magic) Staffs in the Viking Age. Vienna: Fassbaender.

Gardeła, L., 2017. Bad Death in the Early Middle Ages: Atypical burials from Poland in a comparative perspective. Rzeszów: Zimowit.

Gilchrist, R., 1999. Gender and Archaeology: Contesting the past. London: Routledge.

Giles, M., 2009. Iron Age bog bodies of north-western Europe. Representing the dead. Archaeological Dialogues 16, 75-101.

Green, M., 1999. Humans as ritual victims in the later prehistory of western Europe. Oxford Journal of Archaeology 17, 169-89.

Griffiths, D., 2010. Vikings of the Irish Sea: Conflict and assimilation AD 790-1050. Stroud: History Press.

Hedeager, L. 2011. Iron Age Myth and Materiality: An archaeology of Scandinavia AD 400-1000. London: Routledge.

Hedenstierna-Jonson, C., A. Kjellström, T. Zachrisson, et al., 2017. A female Viking warrior confirmed by genomics. American Journal of Physical Anthropology 164, 853-60.

Heide, E., 2006. Spinning seidr, in Old Norse Religion in Long-term Perspectives: Origins, changes and interactions, eds A. Andrén, K. Jennbert \& C. Raudvere. Lund: Nordic Academic Press, 164-8.

Hillerdal, C., 2009. People in Between: Ethnicity and material identity, a new approach to deconstructed concepts. Uppsala: Uppsala universitet.

Hraundal, T.J., 2013. The Rus in Arab Sources: Cultural Contacts and Identity. $\mathrm{PhD}$ thesis, University of Bergen.

Hubert, H. \& M. Mauss, M. 1964. Sacrifice: Its nature and function. Chicago (IL): University of Chicago Press.

Jensen, B., 2016. Sacrifice and execution: ritual killings in Viking Age Scandinavian society, in Beyond War: Archaeological Approaches to Violence, eds A. GarcíaPiquer \& A. Vila-Mitjà. Newcastle: Cambridge Scholars Publishing, 1-22.

Jesch, J., 1991. Women in the Viking Age. Woodbridge: Boydell Press.

Karras, R.M., 1988. Slavery and Society in Medieval Scandinavia. New Haven (CT): Yale University Press.

Lund, J., 2017. Connectedness with things. Animated objects of Viking Age Scandinavia and early medieval Europe. Archaeological Dialogues 24, 89-108.

Lunde, P. \& C. Stone, 2012. Ibn Fadlān and the Land of Darkness: Arab travellers in the far north. London: Penguin.

McKeithen, J.E., 1979. The Risalah of Ibn Fadlan: An Annotated Translation with Introduction. $\mathrm{PhD}$ thesis, Indiana University.

McLeod, S., 2011. Warriors and women: the sex ratio of Norse migrants to eastern England up to 900 AD. Early Medieval Europe 19, 332-53.

McLeod, S., 2018. Human sacrifice in Viking Age Britain and Ireland. Journal of the Australian Early Medieval Association 14, 71-88. 
Moen, M., 2011. The Gendered Landscape: A discussion on gender, status and power in the Norwegian Viking Age landscape. Oxford: Archaeopress.

Moen, M., 2019a. Challenging Gender: A Reconsideration of Gender in the Viking Age Using the Mortuary Landscape. PhD thesis, University of Oslo.

Moen, M., 2019b. Gender and archaeology: where are we now? Archaeologies 15, 206-26.

Moen, M., forthcoming. Divided territory, no man's land or neutral ground: a discussion of gender differences in mortuary contexts, in Weaving War, eds K. Kjesrud \& F. Iversen.

Monikander, A., 2010. Våld och vatten. Våtmarkskult vid Skedemosse under järnåldern [Violence and water. Wetland cult at Skedemosse during the Iron Age]. $\mathrm{PhD}$ thesis, University of Stockholm.

Montgomery, J.E., 2000. Ibn Fadlan and the Rusiyyah. Journal of Arabic and Islamic Studies 3, 1-25.

Näsström, B.-M., 2001. Blót: tro og offer i det førkristne Norden [Blót: violence and sacrifice in the pre-Christian Nordics]. Oslo: Pax.

Naumann, E., M. Krzewińska, A. Götherström \& G. Eriksson, 2014. Slaves as burial gifts in Viking Age Norway? Evidence from stable isotope and ancient DNA analyses. Journal of Archaeological Science 41, 533-40.

Price, N.S., 2002. The Viking way: Religion and war in late Iron Age Scandinavia. (Aun 31.) Uppsala: Uppsala University Dept of Archaeology and Ancient History.

Price, N., 2008. Dying and the dead: Viking Age mortuary behaviour, in The Viking World, eds S. Brink \& N. Price. London: Routledge, 257-73.

Price, N., 2010. Passing into poetry: Viking Age mortuary drama and the origins of Norse mythology. Medieval Archaeology 54, 123-56.

Price, N., 2012. Mythic acts: material narratives of the dead in Viking Age Scandinavia, in More than Mythology: Narratives, ritual practices and regional distribution in pre-Christian Scandinavian religions, eds C. Raudvere \& J.P. Schjødt. Lund: Nordic Academic Press, 13-46.

Price, N. S. 2019. The Viking Way: Magic and mind in late Iron Age Scandinavia. Oxford: Oxbow.

Price, N., C. Hedenstierna-Jonson, T. Zachrisson, et al., 2019. Viking warrior women? Reassessing Birka chamber grave Bj.581. Antiquity 93, 181-98.

Pyburn, K.A., 2004. Rethinking complex society, in Ungendering Civilization, ed. K.A. Pyburn. New York (NY): Routledge, 1-46.

Raffield, B., 2018. Raiding, slaving and the economies of unfreedom in the Viking diaspora. The $S A A$ Archaeological Record 18(3), 32-4.

Schmid, U., 2018. The Normanist debate in Russia and its contemporary repercussions, in Handbook of Pre-Modern Nordic Memory Studies, eds J. Glauser, P. Hermann \& S.A. Mitchell. Berlin: De Gruyter, 927-32.

Schwartz, G.M., 2017. The archaeological study of sacrifice. Annual Review of Anthropology 46, 223-40.
Solli, B., 1998. Odin the 'queer'? Om det skeive i norrøn mytologi. Universitets Oldsakssamlings årbok 1997/ 1998, 7-42.

Solli, B., 2002. Seid: myter, sjamanisme og kjønn i vikingenes tid [Seid: myths, shamanism and gender in the Viking Age]. Oslo: Pax.

Solli, B., 2004. Det norrøne verdensbildet og ethos. Om kompleksitet, kjønn og kontradiksjoner [The Old Norse world view and ethos. On complexity, gender and contradictions], in Ordning Mot Kaos [Order and chaos], eds A. Andrén, K. Jennbert \& C. Raudvere. Lund: Nordic Academic Press, 253-87.

Solli, B., 2008. The Norse god Odin and 'Holy white stones' - a queer interpretation, in Facets of Archaeology: Essays in honour of Lotte Hedeager on her 60th birthday, eds K. Childis, J. Lund \& C. Prescott. Oslo: Unipub Institutt for arkeologi, konservering og historiske studier, Universitetet i Oslo, 275-89.

Stalsberg, A., 2001. Visible women made invisible: interpreting Varangian women in old Russia, in Gender and the Archaeology of Death, eds B. Arnold \& N.L. Wicker. Walnut Creek (CA): AltaMira, 65-79.

Steinsland, G., 2005. Norrøn religion: myter, riter, samfunn [Old Norse religion: myths, rituals and society]. Oslo: Pax.

Sundqvist, O. 2007. Kultledare $i$ fornskandinavisk religion [Cult leaders in Old Norse religion]. Uppsala: Uppsala University Dept of Archaeology and Ancient History.

Symonds, L., T.D. Price, A. Keenleyside \& J. Burton, 2014. Medieval migrations: isotope analysis of early medieval skeletons on the Isle of Man. Medieval Archaeology 58, 1-20.

Upham, T.M., 2019. Equal Rites: Parsing Rus' Gender Values Through an Arabic Lens. MA thesis, University of Iceland.

Vanggaard, T., 1972. Phallós. A symbol and its history in the male world. New York (NY): International Universities Press.

Warmind, M.L., 1995. Ibn Fadlan in the context of his age, in The Ship as Symbol in Prehistoric and Medieval Scandinavia, eds O. Crumlin-Pedersen \& B.M. Tye. Copenhagen: National Museum of Denmark, Department of Archaeology and Early History, 131-7.

Weale, M.C., 2019. An osteoarchaeological assessment of Viking burial on the Isle of Man. Isle of Man Studies $16,801-9$.

Williams, H., 2016. Manx Vikings 2: Interpreting and Displaying Human Sacrifice. ARCHAEOdeath Death $\mathcal{E}$ Memory - Past $\mathcal{E}$ Present. https://howardwilliamsblog. wordpress.com/2016/01/24/manx-vikings-2-interpretingand-displaying-human-sacrifice/ (accessed 10 March 2021).

Wilson, D.M., 2008. The Vikings in the Isle of Man. Aarhus: Aarhus University Press. 
Wylie, A., 2007. Doing archaeology as a feminist: introduction. Journal of Archaeological Method and Theory 14, 209-16.

\section{Author biography}

Marianne Moen is an archaeologist based in Oslo. Research interests include archaeological theory, gender archaeology and feminist theory, Viking Age archaeology, mortuary archaeology and critical heritage perspectives on the past. Moen is currently a postdoctoral researcher with the project Human Sacrifice and Value (NRC-275947, PI Rane Willerslev) at the Museum of Cultural History, University of Oslo.
Matthew J. Walsh is an American anthropological archaeologist. He has worked as an archaeologist throughout much of the North American West, as well as in the Kuril Islands of the Russian Far East, Chilean Patagonia and Greenland. His research focuses on modelling processes of cultural evolution, adaptation and cultural transmission across diverse case studies and societies. His current work explores the diversity and logics of ritual violence and sacrificial practices from prehistory into the contemporary era. Walsh is currently a postdoctoral researcher with the project Human Sacrifice and Value (NRC-275947, PI Rane Willerslev) at the Museum of Cultural History, University of Oslo. 